\title{
THE CAUSTIC CALCINATION OF DOLOMITE AND ITS USE IN SORREL CEMENTS ${ }^{1}$
}

\author{
By G. A. BOLE AND J. B. SHaw
}

ABSTRACT

A method for calcining dolomite in which the pressure of carbon dioxide is controlled is described. Less than $1 / 2$ of one per cent of lime is liberated. Material was calcined in ton lots using external heating. Two types of retort were used: wrought iron and fire clay. Floors were laid from the material so calcined and physical tests made on the calcine to determine its availability as a stucco material.

The effect of time, temperature, and pressure of carbon dioxide upon three types of dolomite is brought out.

Dolomites are either double salts or solid solutions or mixtures of the two.

The effect of lime and silica is pointed out.

Dissociation, tensile strength, volume change, time of set, and weather test data are given.

\section{Introductory}

During the past few years the demand for a properly calcined caustic magnesia for use in the building industries has increased many fold. The oxide is used in two general ways: First, mixed with from 20 to 40 per cent of filler (asbestos, wood fiber, ground cork, etc.) and appropriate coloring oxides it is made into a composition flooring; second, mixed with 50 to 60 per cent sand and 20 to 30 per cent silex it makes an excellent stucco material. The general practice is to mix these compositions with sufficient 20 to $22^{\circ} \mathrm{Be}^{\mathrm{MgCl}} \mathrm{Mg}_{2}$ to spread properly when an excellent cement results.

A rather pure magnesite is necessary to produce a satisfactory material using the present burning practice due to the fact that all carbonates present are decomposed. Free lime even in amounts under 2 per cent is detrimental to the life of an oxychloride cement and in quantities over 3 per cent causes early disintegration. With this thought in mind and in view of the fact that high magnesia ore is not found near the centers of consumption, investigations were undertaken by the authors ${ }^{2}$ to determine whether or not ore low in magnesia and high in lime, such as the dolomites, could not be used for the purpose. It is evident then that ores high in calcium carbonate must not be burned in such manner as to liberate free lime.

\section{Effect of Time, Temperature and Pressure}

Since the pressure of carbon dioxide in equilibrium with calcium oxide and calcium carbonate at temperatures as low as $650^{\circ} \mathrm{C}$ as shown by Johnston $^{3}$ is appreciable, it is evident that it is impossible to burn a dolomite at this temperature in any of the kilns in use at the present time for

1 Received April 25, 1922.

2 Shaw and Bole, Jour. Amer. Ceram. Soc., 5, 311 (1922).

Johnston, Jour. A mer. Chem. Soc., 32, 938-46 (1910). 
burning magnesites, without liberating lime. The present general practice with magnesites is to burn in an updraft kiln, only a small amount of the present production coming from rotary kilns.

Aside from the above considerations there are two objections to burning the ore at a temperature as low as $650^{\circ} \mathrm{C}$. First is the consideration that cements made from ores burned below $700^{\circ} \mathrm{C}$ are not as satisfactory as those made from an oxide burned between $700^{\circ}$ and $800^{\circ} \mathrm{C}$. This is not a generally recognized fact and the explanation is not clear. The cause should be investigated. An oxide calcined at $725^{\circ} \mathrm{C}$ or thereabouts seems to have different physical characteristics from that burned at either a higher or lower temperature. Illustrative of this fact, the following table shows the effect of temperature of calcination on a magnesite low in lime used in a stucco mix. The same relation was later found to hold when using dolomite mixes. (See Table V.)

\begin{tabular}{|c|c|c|c|c|}
\hline \multirow{2}{*}{\multicolumn{5}{|c|}{${ }_{650^{\circ} \mathrm{C}} \mathrm{TABLE} \mathrm{I}_{700^{\circ} \mathrm{C}}$}} \\
\hline & $650^{\circ} \mathrm{C}$ & $700^{\circ} \mathrm{C}$ & $750^{\circ} \mathrm{C}$ & $850^{\circ} \mathrm{C}$ \\
\hline $\begin{array}{l}\text { Time of set } \\
\text { Tensile strength ( } 24 \text { hours) }\end{array}$ & $\begin{array}{c}41 / 2 \mathrm{hrs} \\
350\end{array}$ & $\begin{array}{l}3 \mathrm{hrs} . \\
480\end{array}$ & $\begin{array}{c}31 /, \mathrm{hrs} \\
500\end{array}$ & $\begin{array}{l}5 \text { hrs. } \\
450\end{array}$ \\
\hline $\begin{array}{l}\text { Weathering (per cent of orig } \\
\text { strength recovered) }\end{array}$ & 63 & 80 & 80 & 72 \\
\hline
\end{tabular}

The cement, the physical characteristics of which are given in the above table was of a (1 MgO-2 silex-5 sand) stucco mix, made up with $22^{\circ}$ Bé $\mathrm{MgCl}_{2}$ solution.

The time of set was in all cases determined by the Gilmore needle.

The weathering tests consisted of allowing the tensile strength briquettes to age 14 days and taking an average of the breaking strength of three briquettes as the dry strength. Six briquettes were then soaked in water three alternate days (24-hour periods), and three of the six broken wet. 'The others were allowed to dry out for two days in normal air and then broken. This average divided by the average dry strength at 14 days was taken as the recovered strength indicated in Table I.

The second disadvantage referred to is the time element in burning. Some dolomites will calcine very much more quickly at temperatures below $750^{\circ} \mathrm{C}$ than will others. A study was made of this feature of the burning problem with the results indicated in Figure 1. A sample of 0.5 grams under one atmosphere of carbon dioxide was heated in a small quartz side delivery tube in an electric furnace at the rate of $1^{\circ}$ per minute until a temperature of $950^{\circ} \mathrm{C}$ was reached. The evolved carbon dioxide was collected over mercury in a graduated cylinder and the volume of gas evolved at each temperature observed.

A distinct lag appears in a time-temperature curve at $750^{\circ} \mathrm{C}$ due to the endothermic reaction $\mathrm{MgCO}_{3} \rightarrow \mathrm{MgO}+\mathrm{CO}_{2}-X$ calories in the case of 
dolomite No. 3, but No. 1 shows no distinct break. Bleininger and Emley ${ }^{1}$ found this same break, but do not point out that it holds for only one type of dolomite.

Dolomite No. 1 was of the dense variety, No. 2 finely crystalline, and No. 3 was a highly crystalline stone. When later tried out in a semi-commercial way it was found that No. 1 could be calcined advantageously at $650^{\circ} \mathrm{C}$, while No. 3 dissociated so slowly below $750^{\circ} \mathrm{C}$, that it was not a commercial proposition to calcine below that temperature. It so happened that No. 3 was the most desirable one of the three on account of its pure white color and the ease with which it could be milled. The chemical analysis of the above mentioned ores indicated the following compositions:

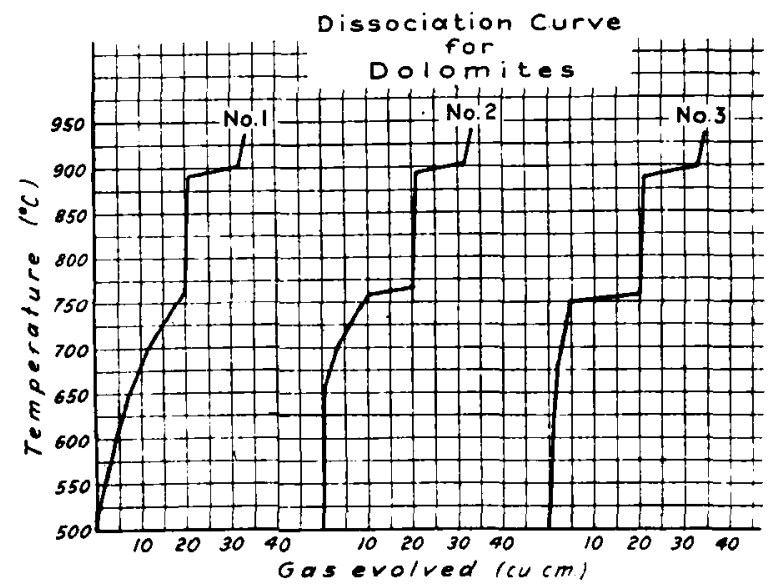

Fig. 1.

$\begin{array}{lrrr} & \text { TABlE II } & & \\ & \text { No. } 1 & \text { No. } 2 & \text { No. 3 } \\ \mathrm{MgCO}_{3} & 39.40 & 46.20 & 43.32 \\ \mathrm{CaCO}_{3} & 59.10 & 53.60 & 55.21 \\ \mathrm{SiO}_{2} & .35 & .25 & 1.00 \\ \mathrm{R}_{2} \mathrm{O}_{3} & .82 & .65 & .46\end{array}$

In light of the above data certain dolomites, it would seem, can be considered to be solid solutions from which $\mathrm{MgCO}_{3}$ separates and dissociates progressively as the temperature is raised- $\mathrm{CO}_{2}$ pressure being held constant - while others would seem to be a double salt with a decomposition temperature of $750^{\circ} \mathrm{C}$, while still others are a mixture of the two.

The above considerations are only tentative, but seem to explain this peculiar behavior of the dolomites better than any suggestion yet offered. The whole question is to be attacked microscopically with phase-rule interpretation.

1 Trans. Amer. Ceram. Soc., 13, 618 (1911). 


\section{Effect of Silica}

It was further found that not all dolomites would make up to a satisfactory cement even when burned under the most favorable conditions of temperature-time - pressure. The unsatisfactory stones were found to be all high in silica. The analysis of a stone burning to a particularly unsatisfactory oxide was as follows:

$\begin{array}{lcccc}\mathrm{CaO} & \mathrm{MgO} & \mathrm{SiO}_{2} & \mathrm{R}_{2} \mathrm{O}_{3} & \text { L.O.I. } \\ 29.15 & 20.00 & 6.10 & .55 & 44.50\end{array}$

This stone was classified by the quarrymen as a water lime. Whether there is a calcium silicate formed at such a low temperature (under $850^{\circ}$ C) seems to be problematical, but worthy of investigation. We have not been able to make a satisfactory cement from any ore containing more than 4 per cent $\mathrm{SiO}_{2}$.

\section{Method of Burning}

The calcination of the ores was carried out in two different types of retorts; the chamber containing the ore in the one case being of wrought iron and in the other of a fire clay body. The gas-tight chamber containing the ore was so constructed as to give perfect control of the atmosphere within. A tube leading from the retort beneath a water seal kept the pressure of the carbon dioxide inside the retort at one atmosphere. The seal indicated when the calcination was completed by a slowing down and final cessation of evolved gas. The retort was heated externally by natural gas in a suitably constructed furnace. The temperature of the furnace was carefully regulated within $25^{\circ}$ of any desired temperature. The two calcining chambers had a capacity of one-half and one and one-half tons, respectively. The time necessary for the calcination in both cases was from 10 to 12 hours.

In all about 15 tons of material was calcined at a temperature varying from 700 to $800^{\circ} \mathrm{C}$. Floors were laid using this material together with suitable filler. The material set up in four to five hours too stiff for further troweling, was in use the second day after laying. These floors have been in service two years and are in perfect condition and giving good satisfaction.

\section{Stucco}

Realizing that an ore containing, when burned, only 28 per cent of $\mathrm{MgO}$ and as much as 70 per cent limestone was better suited for a stucco material than for flooring, where in many cases as high as 50 per cent of $\mathrm{MgO}$ is preferred in the final composition, experiments were undertaken to determine whether this material would make a good stucco which would resist the weather. 
The weather test outlined above was applied to two dolomites widely different in physical characteristics. No. 1 and No. 3, whose calcination curves are shown in Table I, were chosen, together with a so-called Canadian magnesite with the following composition.

$\begin{array}{cccc}\mathrm{MgCO}_{3} & \mathrm{CaCO}_{3} & \mathrm{SiO}_{2} & \mathrm{R}_{2} \mathrm{O}_{3} \\ 78.05 \% & 20.10 \% & 1.60 \% & .70 \%\end{array}$

The ores were calcined at $750{ }^{\circ} \mathrm{C}$ in a retort as described above and made up into a stucco mix. The results of the weathering tests are shown in Table III.

\begin{tabular}{|c|c|c|c|}
\hline \multicolumn{4}{|c|}{ TABLE III } \\
\hline & No. 1 & No. 3 & No. 4 \\
\hline Tensile strength (14 days) & 630 & 825 & 538 \\
\hline Wet strength & 330 & 300 & 234 \\
\hline Recovered strength & 486 & 410 & 535 \\
\hline
\end{tabular}

The recovered strength of No. 4 was remarkable, No. 1 very satisfactory, while No. 3 , in spite of its high dry strength, showed an unsatisfactory recovery.

The recovery of No. 1 and No. 4 is superior to 80 per cent of the "magnesite oxides" at present on the market made up in similar mixes. No. 3 would probably prove to be an unsatisfactory stucco material.

\section{Overburning}

It was thought desirable to determine whether the portion of the sample in direct contact with the hot walls was being overburned, so an inside cylinder was fixed within the retort in such a manner that the portion in direct contact with the hot walls could be removed separately from the portion in the center of the retort. A sample was calcined at $750^{\circ} \mathrm{C}$ in this manner and the free lime determined by the ammonium chloride-potassium permanganate titration process. It was found that the difference in the free lime was well within the experimental error inherent in the method. The amounts found were, respectively, 0.36 and 0.42 per cent. Physical tests were run on the two samples with the following results.

TABLE IV
$\begin{gathered}\text { Sample from } \\ \text { inner tube }\end{gathered}$

From the above data it is evident that there was no overburning in any part of the retort. 


\section{Temperature Range}

Since, as previously pointed out, it is more economical to calcine a dolomite at comparatively high rather than at low temperature, it was thought desirable to know the burning range of any given ore. Accordingly, three 20-pound samples were calcined at temperatures ranging from $700^{\circ}$ to $825^{\circ} \mathrm{C}$. The following table records the results of the tests:

\section{Time of set \\ Tensile strength lbs. per sq. in. (averages)}

Linear change

Weathering

lbs. per sq. in.

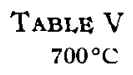

765

280

400

$750^{\circ} \mathrm{C}$
$41 / 4 \mathrm{hrs}$
520
800
910
$\mathrm{Nil}$
$.06 \%$
800
270
380

While the burning temperature did not show great effect on the tensile strength, it did indicate that the lower temperatures gave a better product, as indicated by the change of volume, time of set, and somewhat less clearly, in the weather tests. In no case was there more than 0.45 per cent free lime found.

Whether these results will be borne out in practice can only be proven by time, but the indications would point to the use of properly calcined dolomite as a source for magnesium oxide used in the stucco trade.

\section{Summary and Conclusions}

It has been pointed out that: (1) Dolomites can be calcined in such a way as to liberate the magnesium oxide and leave the calcium carbonate undecomposed by controlling the pressure of the carbon-dioxide.

(2) Dolomites having practically the same chemical composition may differ radically in physical constitution, and an explanation of the cause is offered, i. e., that some dolomites are solid solutions and others double salts, while still others are a mixture of the same.

(3) The best temperature for calcining ore to be used in a sorrel cement was found to be approximately $725-750{ }^{\circ} \mathrm{C}$.

(4) Ores high in silica make an inferior cement.

DEPT. OF CERAMICS

N. Y. Stath School of Chramics

AI,FRED, N. $\mathbf{Y}$. 